Power, Resistance, and Slavery in the United States*

Ryan Light

University of Oregon

Vincent J. Roscigno

Ohio State University

*Please direct all correspondence to Ryan Light, Department of Sociology, University of Oregon, light@uoregon.edu 
Power, Resistance, and Slavery in the United States

\begin{abstract}
In this article, we build on prior sociological theory pertaining to power as well as historical research on antebellum slavery to offer an integrated framework of subordinate resistance - a framework that incorporates a matrix of potential responses ranging from collective action, to symbolic resistance, to projective agency, and even quiescence. Using text networks as an index, we then analyze a rich collection of antebellum slave narratives $(n=128)$ to investigate such response possibilities. These thematic networks, consistent with a large body of historical research on American slavery, demonstrate central domains of enslavement in the United States and the diverse resistance strategies that the enslaved employed. Moreover, our more qualitative immersion into these thematic patterns and the narratives themselves - narratives that have been largely overlooked by sociologists — uniquely highlight how particular resistance strategies are deployed in specific everyday contexts and sometimes resolve into what seem, at first glance, to be quiescence. We discuss these findings, and conclude more broadly by highlighting how the sociological study of inequality and power would benefit from attention to the variety of resistance strategies subordinate actors in their everyday lives and in the uneven and sometimes dangerous contexts they traverse.
\end{abstract}

\title{
Keywords
}

Power, Resistance, Slavery, Inequality, Networks, Semantic Network Analysis 


\section{Power, Resistance, and Slavery in the United States}

Power is a fundamental sociological construct and one that thematically bridges analyses of inequality, the efficacy of populations, and collective action. Its associations with inequality are, according to important scholarship in the field (e.g., Blau 1964; Piven 2008; Tilly 1998), ultimately relational—a point that can be easily overlooked unless one considers moments wherein actors combat, resist, or even overturn power relations (e.g., Ewick and Silbey 2003; Hollander and Einwohner 2004; Lamont and Mizrachi 2012; Scott 1990, 2008). Social movement scholars have been especially informative in this regard, noting how subordinates, even in extreme environments (e.g., Einwohner and Maher 2011; Maher 2010; Scott 2008), sometimes collectively combat hierarchical relations through, for example, group identity formation (e.g., Polletta and Jasper 2001) and resource mobilization (e.g., McCarthy and Zald 1977). But what resistance strategies are available to disadvantaged actors especially when settings are so unequal from the start? And, how do types of resistance relate one another and to the everyday lives of those who are experiencing domination?

Building upon established research on resistance (e.g. Scott 1990 and Hollander and Einwohner 2004), we develop in this article a typology of subordinate response that considers a range of action from individual quiescence to group mobilization. We specifically build on classic statements on the relationship between power and culture (e.g. Bourdieu 1989, 1991; Lukes 2005; Scott 1990) and connect this work to socio-historical research on slavery (e.g. Genovese 1976; Levine 1977; Patterson 1982). Our framework underscores the matrix of responses deployed by subordinate actors depending, at least in part, on the material and interactional settings they traverse. Such theoretical extension is vital, we believe, given: (1) its attention to the intersection of the material and symbolic; (2) the interpretation it affords regarding how behaviors within the micro-political domain of interaction can defy hierarchy by confronting issues of status, recognition and the very definition of one's humanity, and; (3) its acknowledgement of seemingly non-resistant responses, such as quiescence or projective agency ${ }^{1}$ in the

\footnotetext{
${ }^{1}$ Projective agency, which we discuss later, is the ability of actors to imagine future possibilities for action (Emirbayer and Mische 1998). Quiescence, on the other hand, is passive silence due to fear (Pinder and Harlos
} 
face of especially imbalanced power relations. Moreover, our argument speaks to important gaps surrounding sociological interpretations of inequality in everyday life and how "ordinary people claim inclusion, affirm their distinctiveness, contest and denounce stereotyping and claim their rights in the face of discriminatory behavior and other more subtle slights to their sense of dignity" (Lamont and Mizrachi 2012: 366-367; see also Lamont et al. 2016).

Our data are drawn from 128 slave narratives published between 1800 and 1930, collected by the University of North Carolina's Documenting the South Project. Although contemporary sociological research on the South during or just after Reconstruction is relatively robust (e.g., Bloome and Muller 2015; Gullickson 2010; Muller 2018; Ruef 2004 and 2014), with some notable work examining the antislavery movement and/or the antebellum period (e.g., Budros 2004 and 2013; King and Haveman 2008) and growing scholarship identifying how slavery in the United States has contemporary effects (e.g., O’Connell 2012; Reece and O'Connell 2016), few sociologists have studied slave narratives themselves. This is unfortunate, in our view, as narratives like these reflect a "communal utterance" and our best trace of the public and hidden transcripts of the everyday lives of those who are repressed (Gates 1987; Scott 1990; see also especially Patterson 1982). The construction and identification of thematic networks and core domains of enslaved life structure our in-depth qualitative analysis of power arrangements and slaves' responses to those arrangements. Indeed, and while confirming historical insights on how the enslaved resisted slavery materially and symbolically (see Camp 2004), our analyses also extend on prior work by: (1) helping circumvent reductionist pitfalls and/or reliance on singular cases by considering an entire body of narratives and; (2) highlighting the complex, core, and often intersecting contexts and response strategies as defined by the enslaved themselves. We also believe that lessons derived from our discussion and analyses are important for general sociological conceptions of inequality—a point we return to in our conclusing discussion.

2001; Dyne, Ang, and Botero 2003). As we note momentarily, quiescence does not necessarily denote either complicity or resignation. 


\section{POWER, INEQUALITY AND RESISTANCE}

Power - the ability of an actor to impose his/her will in the face of resistance from other(s) according to Weber's (1947) classic and widely-used definition — has been a fundamental construct within sociology since the very origins of the discipline. More contemporary elaborations (e.g., Lukes 2005; Reed 2013; Scott 2008), by acknowledging multiple dimensions of power, provide important groundwork for conceiving of its relational nature and the inequality that both results from and reifies it. Within a multidimensional framework, subordinate capacities to resist are often embedded within cultural or discursive resources (for instance, see Fleming, Lamont and Welburn 2012). Moreover, and noteworthy for our purposes, such theoretical discussions of power parallel lines of inquiry and developments in research on slavery (e.g., Camp 2004).

Scholarship on slavery largely follows the theoretical trajectory famously developed by Lukes (2005), moving from overt forms of domination and attention to collective mobilization, grounded in material structures, to more comprehensive formulations that begin to incorporate cultural hegemony. Lukes' first dimension of power, focusing on overt forms of dominance, parallels early analyses of slavery wherein the focal point is the structural tools and tangible resources used by the master class to reinforce dominance and remove opposition. Take, for instance, Phillips' rather benign account (1918) or that of Stampp (1964), which rests on many (one-dimensional) materialist and economic assumptions surrounding slavery as largely a hegemonic labor system (Weinstein, Gatell, and Sarasohn 1968).

Paternalist views of slavery, unlike more purely structural-materialist accounts, invoke conceptions analogous to Lukes' second dimension of power. Here, and alongside structural resource advantages, the master establishes the rules of interaction in master-slave relationships. The enslaved, for their part, have some capacity to reinterpret conditions to promote their humanity, yet in a manner largely acquiescent to broader structure. Or, as Genovese (1976: 5) writes, "Paternalism created a tendency for the slaves to identify with a particular community thorough identification with its master; it reduced the possibilities for their identification with each other as a class." From this perspective, the only form of tangible opposition occurs in the context of revolts, which we know were relatively rare (Genovese 1976). 
Finally, Patterson's (1982) seminal comparative work on slavery parallels Lukes' third dimension of power wherein "consciousness, interests, and beliefs are altered or manipulated in a manner that shapes compliance, conformity and passive agreement" (identifying reference 2011). Thus, the very possibility of alternative contemplations, including how subordinates see themselves, may be limited (Foucault 1980; see Honneth, Allen and Cooke 2010). While Patterson acknowledges the materialist flavor of chattel slavery, slavery is not defined by it. Rather, he suggests that slavery is also a profoundly symbolic power arrangement embedded in and reified by economic and political structures. It is for this reason that he develops the concept of natal alienation-i.e., the forced removal of the enslaved from all enforceable ties to family and other forms of community — to move beyond materialist definitions of power to one centered on dishonor and a lack of recognition. Enslaved people are viewed as socially dead, unrecognized as a human in any meaningful sense, and isolated within society (Patterson 1982). Social death is a symbolic tool used in the maintenance of the normative hierarchy structuring slave societies.

Although Patterson's comparative work offers little hope of meaningful contestation, he acknowledges that the enslaved were conscious of their position and not always complacent about the prospects of escape. This point raises theoretical questions about if and how the enslaved considered these prospects and whether and when they followed through. Levine's (1977) work on the resilience of the enslaved points to one answer in suggesting that liberation was partially experienced through everyday cultural practices, such as song or religion. The enslaved succeeded in "carving out independent cultural forms" (Levine 1977:30) through a "network of beliefs and practices" (Levine 1977:54), thus challenging natal alienation. ${ }^{2}$ Recognizing such symbolic actions theoretically prods a multidimensional understanding of power and resistance potential, including that surrounding slavery. It also demands full consideration of both the structural conditions that generate and maintain positional inequality and the struggle for both symbolic legitimacy and recognition.

\footnotetext{
${ }^{2}$ Patterson (1982:74) recognizes that, despite attempts by the master class to use "theology of slavery" as an instrument of social control, the development of a unique brand of fundamentalist Christianity offered the enslaved "some room for a sense of dignity before God and before each other."
} 


\section{FORMS OF RESISTANCE}

Prior work on subordinate response and resistance, especially Hollander and Einwohner (2004) and Scott (1990), identifies ways in which forms of resistance may differ. These dimensions often occur in binaries from action/inaction to formal/everyday resistance to cultural/material contestation. We appreciate and expand upon such efforts at typology building by formalizing a theoretical approach to subordinate response that explicitly recognizes not just various resistance responses, but rather how they relate to and coexist alongside one another.

While subordinate actors may, to a certain extent, move back and forth between public and private spaces or discourses, they are likely to draw on strategies with some modicum of intent relative to the setting. That is, survival and resistance are constructed iteratively based on the social landscape, and actors are likely to cobble together a general strategy from the multiple potential responses available to them (see also Fleming, Lamont and Welburn 2012). As illustrated in figure 1, possible responses vary by level of formality and the extent to which they are visible or public. ${ }^{3}$ The formality dimension is closely related to questions of intent: When actors collectively mobilize, their intent is clear. Yet, given the difficulty in determining intent in many social settings (Hollander and Einwohner 2004), we identify variation based on the extent to which subordinate responses engage in formal collective action or more individualized behavior.

Following debates about symbolic power, our typology is also distinguishes as to whether response is visible or covert. Here, resistance moves from visible collective action, a central focus in social movement scholarship, to projective quiescence that often occurs in private solitary moments. Such responses, of course, are not mutually exclusive. Rather, as our framework indicates by the dotted lines between types, one is likely to observe connections between strategies as individuals traverse interactional

\footnotetext{
${ }^{3}$ This figure is not meant to indicate a rigid typology, nor are the dimensions meant to capture the sole axes of interest. As such, the dotted-axes illustrate the fluidity of these strategies.
} 
domains - domains that partially bound or even elicit particular responses. We describe each of these response types in turn.

[Figure 1 About Here]

Recognizing symbolic power and related forms of resistance is, in our view, critical to broader perspectives on power and inequality in so much as social relations, interactions and the corresponding actions and rationales of subordinate actors are more explicitly considered and interrogated. This may be even more pertinent within contexts of extreme inequality wherein the contest for material goods is relatively minor. The enslaved, to be sure, may "reappropriate" masters' goods from time to time, but the accumulated effect of such pilfering has little consequence to prevailing power relations. However, the act of reappropriation and other forms of everyday resistance are, following Scott (1990) and others (e.g., Hallett 2003), symbolically meaningful. This is likely true within slavery, to be sure, but also in less rigid stratification contexts such as contemporary race/ethnic hierarchical interactions (e.g., Lamont et al. 2016) or within everyday workplaces, for that matter, where low status actors regularly challenge poor conditions and status hierarchies in symbolic ways by "loafing," sabotaging, and/or or slowing and circumventing bureaucratic and legal processes (e.g., Burawoy 1979; Ewick and Silbey 2003; identifying reference 2004). As Bourdieu suggests (1989:21), “These symbolic struggles of everyday life and the collective organized struggles of political life have a specific logic which endows them with a real autonomy from the structures in which they are rooted." Moreover, acknowledging them helps avoid the pitfalls of more essentialist preoccupations with either physical or mental forms of contestation (Mitchell 1990).

We define symbolic resistance as the less coordinated acts that have as their aim empowerment, dignity and recognition of humanity, and that are undertaken by those in subordinate positions who otherwise experience both significant constraint and lack the resources relative to more organized collective action. Like everyday resistance generally, symbolic resistance is not episodic, but is diagnostic of broader structures of power (Ewick and Silbey 2003). In an effort to address lingering questions regarding intentionality, we distinguish symbolic resistance (intentional) from projective agency (less 
intentional). Within slave societies, the dominant classes' efforts to enforce and promulgate natal alienation could make even projective acts of agency de facto acts of resistance. Indeed, any act or even thought by an enslaved man or woman that attempts to counteract the condition of slavery could be conceived of in oppositional terms.

The distinction between intentional, symbolic acts of resistance and less intentional expressions of humanity embodied in projective agency (discussed momentarily) is nevertheless important to maintain. Within the narratives we analyze below, and based mostly on prior historical literature, such as Bauer and Bauer (1942), Rawick (1972) and Camp (2004), we expect narrators to express intentional acts consistent with symbolic resistance: learning to read, engaging in clandestine religion, and intentional loafing at work, among others. Our analyses demarcate the core forms that such symbolic resistance takes across the body of narratives, and we distinguish these from more formal resistance, projective agency, and quiescence.

Resistance, of course, may entail actions that are organized, formal and possibly even collective. Unlike symbolic responses to subordination, formal resistance, owing to its reliance on resources, structures and its collective nature, not to mention severity of sanctions, will be relatively rare in the case of slave society (Genovese 1976). In fact, we expect that such acts will be seldom discussed or alluded to in the slave narratives below. The exception may be within historical references, such as Caribbean slave revolts, or with temporal distance from the enslaved life through abstraction, such as within broader philosophical discussions of abolition.

Subordinates, including enslaved populations, along with capacities to formally or symbolically resist, likely incorporate aspects of habitus consistent with the routinization of past behaviors and enact projective dimensions of agency. In this regard, we draw specifically on Emirbayer and Mische's (1998) distinction between past, present and future-oriented agency. They define the projective dimension as "the imaginative generation by actors of possible future trajectories of action, in which received structures of thought and action may be creatively reconfigured in relation to actors' hopes, fears, and desires for the future" (1998:971). Projective agency acknowledges that actors have the ability to conceive of alternative 
possible paths of action when problems arise. This form of agency is embedded in the imaginative process, and reflects the ability to conceive of action without ultimately engaging in formal or symbolically resistant behaviors. Following this point, we expect to find some conscious awareness of alterative paths, including resistance, even when subordinates may not themselves engage in such actions.

Quiescence is passive silence often owing to fear (Pinder and Harlos 2001; Dyne, Ang, and Botero 2003). As a construct, it is largely agnostic to whether actors are approving or disapproving of the conditions that structure their lives, but signals an awareness of one's condition. In fact, subordinate actors within brutal systems of domination likely use quiescence as a mechanism of survival (Dyson 2004). Thus, it is not mere capitulation, nor is it "ennobling" (Patterson 2019). Recognizing this makes explicit the ways in which habitus and the cultural conditions of power pervade subordinates' responses to inequality. Actors embedded in weak positions, even the utter domination consistent with extreme inequality, do not inherently resist in every situation nor are they predisposed to always resist. Intead they may exhibit a public "face" of compliance (Goffman 1955) to subordination. This is not to say, of course, that those who express what appear to be quiescent acts or opinions, such as complementing treatment at the hands of a particular white superordinate, are offering wholesale acceptance of the slave system. They are not, but neither are they operating under an explicitly resistant frame.

We expect that, within our analyses, there will be some elements of quiescence since the enslaved were realistic about what was possible in the system of domination within which they lived. As Levine (1977:134) acknowledges, the folk beliefs of the enslaved were often multi-level, containing both hope in the future and "tactics for short-run survival and maintenance." Similarly, Bauer and Bauer (1942:390) describe how the enslaved engaged "outward forms of compliance," while also engaging in subtle transgression in other moments, such as at work. Thus, for many weak actors in our view, quiescence should be viewed as a "holding pattern" or a type of "maintenance" for other expressions of agency or resistance.

\section{DATA}


Our analyses draw from the University of North Carolina's Documenting the South project. This invaluable data repository consists of a wide range of historical and contemporary sources on the southern United States. The narratives consist of published accounts of slavery from the formerly enslaved themselves. In this analysis, we include those narrative accounts published between 1800 and 1930 $(n=128)$.

Slave narratives are particularly useful because they share a similarity of form consistent with other genres. As Franzosi (2004:8) writes, "Genres have their laws - and laws are always constraining." This parallels Gates' observation that the slave narrative is a "communal utterance" (Gates 1987:ix). While narrative data can be unstructured and cumbersome, their formal similarities encourage systematic analyses. For example, many of the narratives begin with some variant of the phrase "I was born" and include prefatory letters assuring the reader that the narrator is trustworthy and/or committed to abolitionism

While we read such data as a "collective utterance," we also acknowledge that they are probably not inclusive in their content of all resistance possibilities, are by no means completely uniform, and likely have some biases based on how and why they were produced (e.g. whether they were published by an abolitionist organization). Nonetheless, following Fleming, Lamont, and Welburn (2012:410), this corpus allows us to consider "the dialogue members of stigmatized groups carry out (privately or publicly) with the dominant meanings associated with their group." Indeed, this corpus is heterogeneous on any number of dimensions. As reported in Figure 2, for example, we find significant geographical variation - georgraphic variation that surely shaped the patterning and dominant forms of labor described by the narrator. This makes sense since occupation is predicated, in part, on local economic structure. While coding on issues such as place can offer important insights, our theoretical interest and analytic framework demands a more flexible, yet still systematic, attempt to capture the major resistance themes across a large and dense corpus.

[Figure 2 About Here] 


\section{ANALYTIC STRATEGY AND RESULTS}

Sociology has long recognized the importance of capturing diverse voices when examining the dynamics of inequality. Too often, however, those on the bottom rung remain hidden. This is less excusable with the recent development of digital archives alongside advances in computing technology and methodology. Our theoretical arguments above, when coupled with the data derived from the slave narrative corpus, require an analytic approach that simultaneously incorporates the multivocality of subordinate actors, a macro-sensitivity to key patterns, and micro-sensitivity to content and context. For this reason, we draw partly on the techniques of semantic network analysis or text networks - techniques that provide an index (or roadmap) to the more extensive qualitative analyses in which we also engage (see identifying reference 2014; Diesner and Carley 2005; Hoffman et al. 2018; Hunter and Singh 2015; Rule, Cointet, and Bearman 2015).

A semantic network approach represents a basic form of a set of approaches that uses the pattern of co-occurrence between words in texts to construct an overall representative picture of a text collection. In this case, the results of our network analysis consist of a network of words based on co-occurrence in narratives. Here, the nodes are words or themes and the edges are the correlation between them. Themes that appear together in different narratives will be closer together within the network.

The text network that we report provides a systematic assessment of patterns within the content of the collection as a whole. By identifying prominent themes, we avoid overemphasizing particular texts, especially those with especially compelling narratives. Our goal is to describe the variety of survival mechanisms employed by enslaved people consistent with our relational framework. Our approach here is also consistent a relational emphasis in so much as it offers leverage into how themes intersect and the frequency of specific themes (e.g., the Master-Slave relationship compared, for instance, to others, such as more formal, collective acts of rebellion).

Beyond thematic content, the text network findings that we report also allow for sensitivity and attention to the core micro-political domains of everyday life and interaction that the enslaved encountered. Clusters, which we denote with inserted text tags, indicate predominant domains (i.e., 
religion, education, master-slave interaction, etc.) within which such themes are discussed and are located through the widely used Louvain method (Blondel et al. 2008). We pay detailed attention to highly common and correlated concepts, and report centrality indices for the key domains of life under enslavement identified and their interconnections in Table 1. For more detail in these regards, see our methodological appendix.

Importantly, the networks we report provide an index and guide for our qualitative immersion and analyses. In addition to traditional socio-historical methods of analyzing historical text, we used the prominent themes and their associated terms in the course of qualitative immersion into the entire corpus - immersion that helped us identity relevant and, indeed, representative passages. Indeed, the networks guide our analyses and interpretations, while also encouraging observation across the entire collection. Our mixed method approach in this regard parallels is consistent with our theoretical aim to develop a more encompassing understanding of the strategies at subordinates' disposal. It also: (1) draws attention to the more detailed interactional contexts within which resistance, projective agency or quiescence are evidenced to greater or lesser degrees, and; (2) affords grounded observations and lessons regarding the interplay of the material and symbolic elements of inequality and life under enslavement.

\section{Thematic and Interactional Domains of Enslavement in United States}

Our construction and analyses of network of themes provides a broad structural picture of the key interactional domains within which subordination and contention play out. Such a macro "satellite" map, reported in Figure 3 and as noted earlier, serves as a useful guide for qualitative immersion and elaborations regarding the variations, contexts and forms that resistance takes.

[Figure 3 About Here]

First, and most noteworthy in Figure 3, slave discourses cluster around eleven predominant "fields" or interactional domains: everyday life, slave \& master, faith \& prayer, church \& institutions, family, slavery \& race, place \& war, narration \& literacy, economics, politics, and life course. These represent core contexts within which the experiences of slave life are interpreted and communicated, and 
within which content surrounding quiescence, projective agency, and resistance are revealed. Importantly, responses to subordination are hardly limited to one solitary realm. Nor do we find within any given narrative an exclusive focus on only one of the response possibilities. Rather, there is significant complexity in responses to subordination-complexity that cuts across the interactional domains reflected in the text network.

\section{[Table 1 About Here]}

[Figure 4 About Here]

The narrators draw from a toolkit of responses, as we theoretically speculated earlier. Figure 4 offers a network depicting the relationship between thematic text communities, while Table 1 provides an overview of the predominant ways that these themes overlap. For example, the church \& institutions, slave \& master, everyday life, and place $\&$ war clusters are most central within this network based on average betweenness centrality - a measure of relative distance. Importantly, we begin to see systematic, initial evidence of the role that the religion, interactional dynamics between enslaved person and owner, and everyday life encounters play in structuring the network. Examining central portions of the network in finer detail, as we do in Figure 5, provides leverage surrounding how, where and why responses to slavery overlap and vary.

[Figure 5 About Here]

The relative importance of the slave \& master thematic cluster underscores the centrality of this interactional and power-laden relationship in the structuring of the experiences of enslaved people. While maintenance of the power structure within the American South certainly occurred in the multi-level sense, from state, legal and economic forces through deeply engrained and more general cultural structures, more proximate power relations with master and mistresses, overseers, and local watchmen were clearly pivotal. This point is well-established in the historical literature (see Clinton 1982; Fox-Genovese 1988; White 1985 among others).

The everyday life and master-slave clusters, moreover, clearly intersect with one another and with many other thematic domains. Indeed, these central interactive domains about which we are speaking are 
particularly closely linked. While observations associated with the slave trade (e.g. bought.vb and sell.vb) are theoretically separable from issues pertaining to work (e.g. cotton.nn or field.nn), for example, it is clear that, in actuality, they were also part and parcel of the everyday realitities of enslaved people, as described in the slave narrative corpus. And, even more generally, the overlap of domains identified by our network and the centrality indices highlight the importance of overt expressions and forms of powerpower that structured and impacted everyday encounters.

Formal, collective resistance, such as organized rebellions, is rarely discussed in these narrative accounts. With the major exception of Nat Turner's narrative and a handful of others, such as Henson's where collective resistance is mentioned, collective resistance largely fulfills a symbolic role of idealized action. For example, John Brown, mentioned numerous times in the corpus, is often situated alongside Abraham Lincoln or the Underground Railroad as a symbol of change. The politics, slavery \& race, and place \& war clusters suggest that, while less central to the corpus, these more formal types of resistance and the discourses surrounding them certainly existed.

More directly meaningful to resistance was the more proximate master-slave relationship, day-today interactions, and the emotional condition and implications of slavery. It is for this reason that we focus on these specific contexts of interaction, uncovered in our network analysis, and the ways in which symbolic resistance, projective agency and quiescence unfold within them to greater or lesser degrees. Notable, though perhaps not surprisingly, the slave-master cluster indexes the flashpoint of subordinate response, yet many of the themes and responses highlighted also "pass through" the church \& institutions and related faith \& prayer clusters in addition to, importantly, the everyday life cluster. This finding, elaborated upon below, encourages an emergent, multidimensional conception of resistance and the domains within which it is meaningful.

\section{Symbolic Resistance Under Enslavement}

Within the antebellum South, and according to our text network-directed, in-depth qualitative immersion, religion, literacy, and narrative encounters reflect the primary interactional domains within which 
symbolic resistance took place. Relative to religion specifically, the master class attempted to control slaves' access and biblical understandings, and in a manner that reinforced subordination and docility. The enslaved, however, clearly developed a "hidden transcript," clandestinely meeting in the woods under the cover of darkness and building their own brand of Christianity focused on the Bible's emancipatory aspects (Scott 1990).

Such secret religious meetings offered an alternative story about enslaved people's place in the world and, indeed, their status as human beings. Religious practice, in fact, represents the most explicit example of symbolic, often covert, contestation as the "slave community had an extensive religious life of its own, hidden from the eyes of the master" (Raboteau 1978:212). This should perhaps not come as a surprise given that religion and the oppositional credibility claims that may manifest in its practice can often circumvent and speak to a power greater than the state itself (Della Fave 1986). Although the link between religion and contestation has been known for some time, few studies recognize or explicate the relationship between the everyday and often clandestine practice of religion among the enslaved with the political place of religion within abolitionism and during the Reconstruction.

Many of the enslaved explicitly recognize religion as a primary arena of contestation, noting how they countered the master class's use of religion as a means of control. Indeed, some masters used religious ideology to dehumanize the enslaved, echoing the "bestialization" described by Davis (2006) as central to the maintenance of social death. Francis Fedric, for example, describes how his master would gather the young together, ask them to look out over the plantation, and identify the cows, sheep and mules in the pasture. Next, he would say, "Look, you niggers! You have no souls, you are just like those cattle, when you die there is an end of you; there is nothing more for you to think about than living. White people only have souls."

Others owners drew from more subtle religious interpretations to reinforce the subordination of slaves, focusing especially on obedience and subjugation within the Bible itself (Levine 1977:43). As Amanda Smith, among others, admits, they were taught that the greatest sin was disobedience. Importantly, however, many fostered their own contrary interpretations in secret spaces and away from 
the ever-vigilant white gaze. Friday Jones reflects on the emancipatory, yet covert, character of religious practice:

We had to have secret prayer meetings on Saturday nights, and some would have to watch for the patrolmen and hard task-masters, to keep from being surprised, while the others prayed and sung. When the enemy was seen the watch would give the alarm; we would then close the meeting and make our escape, in order to keep our backs from being slashed and salted down.

Efforts to keep the enslaved from practicing religion were widely enforced, and often with violence. In one particularly harrowing account, Francis Fedric, the Virginia house servant mentioned above, describes how his grandmother was tied to a peach tree and flogged forty lashes by her own son, an overseer, for "the crime of attending a prayer-meeting." Efforts to control religious practice were not, according to Charles Ball among others, the result of masters wanting to prevent the enslaved population from seeking solace in spirituality, but rather fear that they "may imbibe with the morality they teach, the notions of equality and liberty, contained in the gospel." Indeed, religious practice re-established humanity and worth, was often undertaken in symbolically resistant ways, and was recognized by slaves themselves as commensurate with running away and insurrection.

Notably, numerous narrators recognized the hypocrisy of the master class's religion. Here, they note that religious "professors" and leaders were owners, and likely to be no more or less cruel than less overtly religious slaveholders. Asking "Is this Christianity? Is it honest or right? Is it doing as we would be done by? Is it in accordance with the principles of humanity or justice?" Henry Bibb lists no less than four former owners who were active in the church and describes how the enslaved were averse to the “pro-slavery doctrine” of obedience preached on his Kentucky plantation. William Craft, making a similar observation about pious slaveholders, establishes an explicit distinction between "true Christianity" and "slave-holding piety."

Religion was by no means the only way that enslaved people symbolically reinforced their sense of personhood. Rather, many directly addressed power relations in everyday conversation. The polemical aspects of both the postbellum and antebellum narratives are often somewhat distinct from the main story; either embedded in prefatory statements or attached essays. On the other hand, some narrators report 
thoughts and conversations that relate to this thematic cluster within the retrospective accounting of their life. The polemical accounts are direct observations of the prejudice and cruelty of the slave system, running counter to the racist "Sambo" generalization promoted by earlier scholars of slavery. Here, narrators note that they were cognizant and critical of the prejudice buttressing the slave system and understood well the sophistication of the racial antagonism reinforcing their subordinate position.

The preservation of social ties, and especially kinship ties, was also a subtle symbolic means of contesting the symbolic violence of natal alienation. The dominant class used the denial of family connection as a mechanism to dehumanize bondsmen and bondswomen, although they balanced this dehumanization with economic considerations (Patterson 1982). Yet, embedded in the domains of everyday life and the master-slave relationship, the enslaved forged public and private familial and pseudo-familial ties. Friday Jones, for example, describes his desire to start a family despite the legal impediments to marriage. Having fallen in love with a woman on a neighboring plantation, Jones asks his master, Col. Jones, for permission to marry her. As Jones writes, "He answered quick and short, 'If you have a wife at home, sir, I'll sell you to a trader. I want you to have a wife at home, sir, I'll buy you a wife."

The unique circumstances of the internal slave trade following the abolishment of the transatlantic slave trade made reproduction a site of contestation. Jones eventually defies his master and gets married, subsequently growing his family despite threats of violence. Drawing attention to the intersection of religion and kinship, Jones perceives the pleasure he takes in his family as a sign from God: "I was raised poor and hard as any slave, but the Lord had elevated me and made me feel that I was more of a man." Jones' struggle to establish and maintain a kinship ties, similar to that of many other narrators such as Harriet Jacobs and Henry Bibb, confronts ongoing efforts by his master to impose natal alienation.

Alongside the domains of religion, polemics, and family, symbolic resistance is also witnessed quite clearly in the context of literacy. Literacy, a common theme within slave narratives, is often difficult to classify. This is because it is, on the one hand, a personal act - a personal act that places one in a more 
expansive community. On the other hand, it squarely fits into the conception of symbolic resistance outlined previously given that one's sense humanity was often regained or preserved through the enactment of reading and writing. Many, in fact, describe how literacy made them feel "more human." Moreover, several, like Frederick Douglass, recognize that confronting the laws preventing literacy is, in itself, an act of counter-power. And, like religion, it can be activated covertly.

That reading and writing were negatively sanctioned by most slaveholders is widely known and documented (Escott 1979; Genovese 1976). The punishment was often severe, though varied depending upon the whims of the master. M.F. Jamison makes this very point. He describes how literacy for the enslaved was illegal and could result in the loss of sight if caught. He goes on further, noting that while the opportunity was severely limited, enslaved people's opportunities to educate themselves "very much depended upon the kindness of their owners."

\section{Projective Agency: Dignity at "work" and the role of personal prayer}

Keeping in mind that the vast majority of the formerly enslaved narrators highlight the torturous means that slaveholders and overseers used to extract the most labor possible, several note a clear sense of pride in their work - pride indicative of some level of agency in the face of domination. These narrators often relate competing with whites in an attempt to earn respect.

George Henry, for example, describes how work contributed to his self-worth. As a child working in the plantation nursery, Henry recognized that he desired jobs that provided a sense of fulfillment: "I was determined to do none of their mean, low, occupations around houses. I aspired to something higher." In his postbellum narrative, he describes how he attained positions overseeing parts of a farm and finally became an enslaved sailor. In each position, he works harder, determined to prove that he was equal to the whites: "I was determined to let them see that though black I was a man in every sense of the word."

Others, particularly skilled laborers, similarly use their work to gain self-respect. William Hayden, for example, parlays his skill as a rope spinner in the country and a competent "man of all work" into some freedom of movement and, along the way, also convinces several whites to teach him how to 
read. James Lindsay Smith, a shoemaker, earns his own shop and also gains freedom of movement. He saves some of the money his business makes and buys a suit, noting that he "was always proud and loved to dress well." He later uses some of the money to escape to Hartford, Connecticut.

In a world of violently enforced constraint, the garnering of self-respect through work is one means the enslaved used to secure some sense of efficacy. Enslaved people in the United States indeed had some control in how and to whom they gave respect, adjudicating when to offer legitimate approbation or not. Of course, enforced respect was an everyday tool used by the master over the slave. As described in the narratives, enslaved people, for their part, could respond to enforced respect in a variety of ways, including conscious false respect. By putting on the "mask" of the respectful servant, for instance, the enslaved could limit the risk of punishment.

William H. Robinson provides an example of such false respect. When a master was known to be humane, it was common for the enslaved to earnestly mourn his death. However, the sale of Robinson's father, much adored amongst slaves on his North Carolina plantation, prompted the bondsmen and bondswomen to turn against their master. Upon the master's death, they felt little yet were obligated to show emotion. They placed saliva on their cheeks to shed "crocodile tears." As Robinson writes, "This may appear very deceptive, but had we not made some demonstration of grief our very lives would have been in danger." This form of deception can hardly be labeled everyday resistance as the enslaved conformed to expectational disadvantage. Yet, the seemingly quiescent behavior is not without purpose. Rather, by providing false respect to their deceased master, the enslaved avoided unnecessary abuse by maintaining the "official transcript" of expected behavior.

Religious practice, as noted previously, clearly captures certain theoretical dimensions of symbolic resistance. However, the enslaved also engaged religion in a much more private and personal manner and, like work, this offered some sense of agency. To be sure, private religious practices contained elements identifiable as symbolic contestation and the broader aim of recognition, yet the intention of such acts was often not explicitly resistant. In fact, it is equally plausible that more personal religious beliefs and moments fulfilled a twin purpose by helping one "get by," while also wedding the 
enslaved to a variant of the master's religion (Patterson 1982). Indeed, for many, religion allowed for expression of personal liberation in the eyes of their god or hope of liberation in the afterlife. Some describe religion as an alternative vision of the natal alienation maintained by whites, often involving only themselves and god. As Elizabeth Keckley writes, "I was born a slave...therefore I came upon earth free in God-like thought, but fettered in action."

Like Keckley, Reverend David Smith, who became an active participant in the establishment of the A.M.E. church in southwestern Ohio, similarly reflects, "I knew very well, if God was able to deliver me from the corrupt influence of the world and the power of Satan, that he was able to deliver me from this slave-holder." William Hayden also states that the "body alone was prostrated in that degraded situation - the mind - the image and the best gift of God to man, was always elevated - it spurned the shackles, and soared to Heaven, where it reveled in Elysium; in blissful concert with its Creator.”

Beyond the hope and peace garnered though prayer and personal devotion, many narrators express hope that solace will be found in heaven. Here, some narrators contemplate a heavenly life reunion with displaced children and deceased relatives, equality, justice, and finding peace in these alternative realities. Separated from her mother, Louisa Picquet, for example, becomes engaged in religion with the understanding that her mother was "a Christian woman" and that they were likely to meet in heaven. J.D. Green's narrative, among others, relates a similar story. While a young boy, Green's mother is sold to another slaveholder. Green writes, "Before parting she advised me to be a good boy, and she would pray for me, and I must pray for her, and hoped we might meet again in heaven."

\section{Quiescence, Power and the Master-Slave Relationship}

Subordinate actors may challenge power imbalances with symbolic acts of resistance or may, as noted previously, engage in alternative scripts, privately or social psychologically, and in a manner consistent with projective agency. To understand the range of actions available to subordinate actors, however, it is essential to consider seemingly "compliant" behavior. Such behavior is hardly synonymous with 
acceptance of the prevailing order. Rather, it can be a strategy of survival - a strategy, as our observations suggest, that may be coupled at times with others that are more clearly resistance- or agency-centered.

Many of the formerly enslaved, for example, contrast the relative benevolence of their masters with the inhumane treatment of others' masters. As Frederick Douglass writes, enslaved people are as likely to make prejudicial judgments as others: "Moreover, slaves are like other people, and imbibe prejudices quite common among others...Indeed, it is not uncommon for slaves even to fall out and quarrel among themselves about the relative goodness of their masters..." As we saw in Figures 3 and 4 and Table 1, the concepts of "master" and "slave" are closely connected in the middle of the network, denoting the centrality of the master-slave relationship within the thematic structure. Statements regarding the "good master" cut to the core of the master-slave relationship. Many compare the relative kindness of their master (or one of their masters) with the inhumane treatment of others' masters (or one of their other masters).

Allen Parker offers a detailed portrait of life on the farm of a "good master." Living in North Carolina, Parker worked on Darias White's plantation. He drove mules for White's lumber operation that fed the growing shipbuilding industry in the antebellum South. White, Parker relates, "took good care of his slaves and was never known to whip one." Many of the enslaved men were allowed to camp out in the woods as they preferred and received small annual cash bonuses for good work. As Parker concludes, "Had all masters been like Darias White there would been far less trouble with the slaves, as under such masters they were generally happy and contented." Parker contrasts White's treatment with Elisha Buck, his subsequent master, who was a "mean poor white." Buck did not provide adequate food for his bondsmen and bondswomen and was not averse to whipping as punishment for transgressions, such as theft.

Even Harriett Jacobs, who writes about the cruelty inherent to the slave system as vividly as any other narrator, concedes that one encountered, on rare occasions, "humane slaveholders." As evidence, she describes a family in her hometown that consisted of a young woman and the bondswoman and children that she inherited. These people formed an unlikely "family" and were extraordinarily close 
according to Jacobs. They were so close, in fact, that the young mistress offered to manumit the bondswoman. However, as Jacobs writes, "They refused to take their freedom, saying that she had always been their best friend, and they could not be so happy any where as with her." However, as Jacobs relates, this family was turned upside down when the young mistress married a man who shared the values more common to the slaveholding class. Known as a "good master" because he kept his enslaved people better clothed than most and used the lash less frequently, he eventually separated the family for profit, thus providing a stark reminder of the "benevolence" of the slaveholding class.

While many of these statements suggest a certain level of quiescence and a tacit understanding that those enslaved people who lived under "good masters" were perhaps more compliant, it is crucial to recognize that both "goodness" on the part of the master class and quiescence on the part of those enslaved are very much context dependent and evaluated in relative terms. Indeed, periodically the calculus shifted. In such scenarios, narrators describe "good masters" abusing enslaved people and enslaved people committing resistant acts. Disentangling the extent to which members of the master class

were actually "good" in a modern sense is hardly worthwhile; however, recognizing "good master" in the relative sense does offer interpretational leverage when considering the heterogeneity of strategies activated among those attempting to live and survive in the face of extraordinary inequality and domination.

\section{CONCLUSION}

Our analyses identify multiple forms of resistance. These forms range from collective grievances and revolt, to symbolic manipulations to preserve hope and basic human dignity, to quiescence that, in actuality, may be a more instantaneous survival reflex in the face of real or perceived constraint or threat. By identifying such unique tools and describing when they are deployed within the context of slavery in the United States we contribute to and extend prior research on resistance generally (e.g. Hollander and Einwohner 2004 and Scott 1990), but also hope to begin a conversation about how responses relate to one another and are embedded in everyday contexts. 
The responses identified in our analysis, of course, merely scratch the surface of the strategies that the enslaved used to survive. Others strategies employed were likely so ubiquitous that the narrators neglected to mention them (e.g., music/gospel songs and humor) or ones so deeply personal, (e.g., how enslaved women tried to avoid sexual contact or rape) that narrators choose to avoid mentioning. Future research, we hope, will continue to explore the many ways that this rich collection of slave narratives can contribute to sociological understanding and theory-building surrounding power, hierarchy and inequality.

Methodologically, analytic strategies aimed toward systematically engaging a broad range of experiences and responses to inequality must correspondigly capture the complex terrain and processes of hierarchy and struggle, not to mention data limitations. In our case, we sought to cast a wide net by taking advantage of texts collected within the framework of the digital humanities. Our sematic network analytic approach offers one way to "read" the "collective utterance" that slave narratives represent. In the case of this article, we "entered" the texts via the network map and iteratively worked between the resulting map and the richness and depth of the texts themselves.

Recent work by Moretti $(2005 ; 2013)$ and others highlights the value of engaging more structural views of text. His argument, which our analysis extends, emphasizes the value of "distant readings" that enable analyses of very large sets of data — data that could not possibly be read by a single person. While computational tools may appear orthogonal to more traditional close readings, it is our position that this need not be the case. Especially with more modestly sized digitized collections, the combination of close and distant readings, or the combination of text networks and qualitative immersion, can help identify and appreciate both the forest and the trees.

Observing the array of responses deployed by enslaved people offered important motivation for our theoretical development given that their experiences and responses, embedded in their own narratives, offers a rare glimpse and lens for understanding subordinate response, even when considering everyday contemporary settings. In this regard, the theoretical and analytic contributions of this article are, in our view, pertinent to more general conceptions of inequality and power, the ways in which they are enacted in the course of everyday interactions, and the capacities of subordinate actors to react and contest in a 
variety of ways (even if not collectively). Moreover, we have been explicit about why and how especially symbolic and discursive forms of resistance and enactments of agency may be meaningful. We see our argument and analyses in these regards as useful to the more general understanding of inequality and the ways in which subordinates maintain dignity, sense of purpose and humanity (see also Hodson 2001; Lamont 2000). The struggle for dignity in an unjust system is not an ennobling experience, rather it illustrates the depths to which oppressive institutions reach and is often experienced as burdensome and effortful.

Recognition, or the process by which people seek to maintain integrity from others through approval, tacit or otherwise, forms the string connecting the everyday practice of power to the everyday maintenance of dignity. Although constrained by structural factors, the giving or receiving of respect plays a central role in daily interactions with others. Like our ability to observe power in action, so too can we see and experience the exercise of recognition: within workplaces, supervisors or coworkers can praise us or demean us; or politicians can vilify populations just as easily as they might celebrate their virtues and worth. When these interactions are determined or influenced by unequal structures and the legacy of deep histories, we feel particularly disconsolate.

No less important than recognizing how inequality impacts subordinate actors through symbolic assaults on dignity and recognition is the observation and our underlying contention in this article that: (1) this occurs not only through structural disadvantage but rather also in the course of everyday interactions, and; (2) that within micro-interactional contexts subordinate actors employ an array of strategies to resist, to forge efficacy, and to engage in quiescence as a means of maintaining and surviving. We correspondingly hope future scholarship will continue exploring more dynamic conceptions of inequality regimes and the many strategies people develop to survive within them. 


\section{References}

Bachrach, Peter, and Morton S. Baratz. 1962. "Two Faces of Power.” American Political Science Review 947-52.

Bauer, Raymond A. and Alice H. Bauer. 1942. "Day to Day Resistance to Slavery." Journal of Negro History 27:388-419.

Blau, Peter M. 1964. Exchange and power in social life. Transaction.

Blondel, V. D., Guillaume, J. L., Lambiotte, R., \& Lefebvre, E. (2008). Fast unfolding of communities in large networks. Journal of Statistical Mechanics 10: P10008.

Bloome, Deirdre, and Christopher Muller. 2015. "Tenancy and African American Marriage in the Postbellum South.” Demography 52: 1409-1430.

Bollen, Johan, Mao, Huina, \& Pepe, Alberto 2011. Modeling public mood and emotion: Twitter sentiment and socio-economic phenomena. In Proceedings of the Fifth International AAAI Conference on Weblogs and Social Media.

Bourdieu, Pierre. 1989. “Social Space and Symbolic Power.” Sociological Theory 7:14-25.

---. 1991. Language and symbolic power. Harvard UP.

Budros, Art. 2011. "Explaining the First Emancipation: Social Movements and Abolition in the US North, 1776-1804." Mobilization 16: 439-454.

---. 2013. "The State Giveth and the State Taketh Away? The Antislavery Movement and the Black

Franchise in the United States, 1691-1842." Sociological Perspectives 56: 377-402.

Burawoy, Michael. 1979. Manufacturing consent: Changes in the labor process under monopoly capitalism. University of Chicago Press.

Camp, Stephanie M. 2004. Closer to freedom: Enslaved women and everyday resistance in the plantation South. Univ of North Carolina Press.

Clinton, Catherine. 1982. The Plantation Mistress: Woman's World in the Old South. Pantheon.

Dahl, Robert A. 1957. “The Concept of Power.” Behavioral Science 2:201-15.

Davis, David Brion. 2006. Inhuman Bondage: The Rise and Fall of Slavery in the New World. Oxford University Press.

Della Fave, L. Richard. 1986. "Toward an Explication of the Legitimation Process.” Social Forces 65:476-500.

Diesner, Jana and Kathleen M. Carley. 2005. "Revealing Social Structure from Texts: Meta-Matrix Text Analysis as a Novel Method for Network Text Analysis." Causal mapping for information systems and technology research: Approaches, advances, and illustrations 81-108. 
Dyne, Linn Van, Ang, Soon and Isabel C. Botero. 2003. "Conceptualizing Employee Silence and Employee Voice as Multidimensional Constructs." Journal of Management Studies 40:13591392.

Dyson, Michael Eric. 2004. The Michael Eric Dyson reader. Basic Books.

Einwohner, Rachel L., and Thomas V. Maher. 2011. "Threat Assessment and Collective-Action Emergence: Death-Camp and Ghetto Resistance during the Holocaust." Mobilization: An International Quarterly 16(2):127-46.

Emirbayer, Mustafa, and Ann Mische. 1998. "What Is Agency?” American Journal of Sociology 103(4):962-1023.

Escott, Paul D. 1979. Slavery Remembered: A Record of Twentieth-Century Slave Narratives. UNC Press Books.

Ewick, Patricia and Susan Silbey. 2003. "Narrating Social Structure: Stories of Resistance to Legal Authority." American Journal of Sociology 108:1328-72.

Ewick, Patricia and Susan S. Silbey. 1998. The Common Place of Law: Stories from Everyday Life. University of Chicago Press.

Fleming, Crystal M., Michéle Lamont and Jessica S. Welburn. 2012. “African Americans Respond to Stigmatization: The Meanings and Salience of Confronting, Deflecting Conflict, Educating the Ignorant and 'Managing the Self." Ethnic and Racial Studies 35:400-417.

Fox-Genovese, Elizabeth. 1988. Within the Plantation Household: Black and White Women of the Old South. University of North Carolina Press.

Franzosi, Roberto. 2004. From words to numbers: Narrative, data, and social science. Cambridge University Press.

Fraser, Nancy. 2001. "Recognition without Ethics?” Theory Culture Society 18(2-3):21-42.

---. 2008. Adding Insult to Injury: Nancy Fraser Debates Her Critics, edited by Kevin Olson. Verso.

Fraser, Nancy and Axel Honneth. 2003. Redistribution or recognition?: a political-philosophical exchange. Verso.

Foucault, Michel. 1980. Power/Knowledge: Selected Interviews and Other Writings, 1972-1977, edited by Colin Gordon. Vintage.

Gates, Henry Louis. 1987. The Classic Slave Narratives. New Amer Library.

Gaventa, John. 1982. Power and powerlessness: Quiescence and rebellion in an Appalachian valley. University of Illinois Press.

Genovese, Eugene. D. 1976. Roll, Jordan, roll: The world the slaves made. Random House.

Goffman, Erving. 1955. "On face-work: An analysis of ritual elements in social Interaction." Psychiatry 18: 213-231. 
Gomes, Peter J. 1996. The Good Book: Reading the Bible with Mind and Heart. Avon Books.

Gullickson, Aaron. 2010. "Racial Boundary Formation at the Dawn of Jim Crow: The Determinants and Effects of Black/Mulatto Occupational Differences in the United States, 1880." American Journal of Sociology 116: 187-231.

Hallett, Tim. 2003. "Symbolic Power and Organizational Culture.” Sociological Theory 21(2):128-49.

Hirschman, Albert O. Exit, Voice, and Loyalty. Harvard University Press.

Hodson, Randy. 2001. Dignity at Work. Cambridge University Press.

Hoffman, Mark Anthony, Jean-Philippe Cointet, Philipp Brandt, Newton Key, and Peter Bearman. 2018. "The (Protestant) Bible, the (printed) sermon, and the word (s): The semantic structure of the Conformist and Dissenting Bible, 1660-1780." Poetics 68: 89-103.

Hollander, Jocelyn A., and Rachel L. Einwohner. 2004. “Conceptualizing Resistance.” Sociological Forum 19(4):533-54.

Honneth, Axel, Amy Allen, and Maeve Cooke. 2010. "A conversation between Axel Honneth, Amy Allen and Maeve Cooke, Frankfurt am Main, 12 April 2010."Journal of Power 3: 153-170.

Hunter, Starling David and Saba Singh. 2015. "A network text analysis of Fight Club.” Theory and Practice in Language Studies 5:737.

King, Marissa D., and Heather A. Haveman. 2008. "Antislavery in America: The press, the pulpit, and the rise of antislavery societies.” Administrative Science Quarterly 53: 492-528.

Lamont, Michéle. 2000. The Dignity of Working Men: Morality and the Boundaries of Race, Class and Immigration. Russell Sage.

Lamont, Michéle and Nissim Mizrachi. 2012. "“Ordinary People Doing Extraordinary Things: Responses to Stigmatization in Comparative Perspective." Ethnic and Racial Studies 35:365-381.

Lamont, Michéle, Graziana Silva, Joshua Guetzkow, Jessica Welburn, Nissim Mizrachi, Hanna Herzog and Elisa Reis. 2016. Getting Respect: Dealing with Stigmatization and Discrimination in the United States, Brazil and Israel. Princeton UP.

Lamont, Michéle, Jessica S. Welburn, and Crystal M. Fleming. 2013. "Responses to Discrimination and Social Resilience Under Neoliberalism: The United States Compared." Pp. 129-157 in Social Resilience in the Neoliberal Age, Peter A Hall and Lamont, Michèle (eds.). Cambridge UP

Levine, Lawrence W. 1977. Black Culture and Black Consciousness. Oxford UP.

Lukes, Steven. 2005. Power: A Radical View. $2^{\text {nd }}$ edition. Palgrave Macmillan.

Maher, Thomas V. 2010. "Threat, Resistance, and Collective Action The Cases of Sobibór, Treblinka, and Auschwitz." American Sociological Review 75(2):252-72.

McCarthy, John D., and Mayer N. Zald. 1977. "Resource Mobilization and Social Movements: A Partial Theory." American Journal of Sociology 1212-41. 
Mitchell, Timothy. 1990. “Everyday Metaphors of Power.” Theory and Society 19(5):545-77.

Mohr, John W., and Petko Bogdanov. 2013. "Introduction-Topic Models: What They Are and Why They Matter." Poetics 41(6):545-69.

Moretti, Franco. 2005. Graphs, Maps, and Trees: Abstract Models for Literary History. Verso.

---. 2013. Distant Reading. Verso.

Muller, Christopher. 2018. "Freedom and convict leasing in the Postbellum south." American Journal of Sociology 124: 367-405.

de Nooy, Wouter, Andrej Mrvar, and Vladimir Batagelj. 2005. Exploratory Social Network Analysis with Pajek. Cambridge University Press.

O'Connell, Heather A. 2012. "The impact of slavery on racial inequality in poverty in the contemporary US South." Social Forces 90: 713-734.

Patterson, Orlando. 1982. Slavery and Social Death: A Comparative Study. Harvard University Press.

---. 2019. "The denial of slavery in contemporary American sociology." Theory and Society 48:903-914.

Phillips, Ulrich B. 1918. American negro slavery: a survey of the supply, employment and control of negro labor as determined by the plantation regime. D. Appleton incorporated.

Pinder, Craig C. and Karen P. Harlos. 2001. "Employee Silence: Quiescence and Acquiescence as Responses to Perceived Injustice." Research in Personnel and Human Resources Management 20:331-370.

Piven, Frances Fox. 2008. “Can Power from Below Change the World?” American Sociological Review 73:1-14.

Polletta, Francesca, and James M. Jasper. 2001. "Collective Identity and Social Movements." Annual Review of Sociology 27: 283-305.

Raboteau, Albert J. 1978. Slave Religion: The "Invisible Institution" in the Antebellum South. Oxford University Press.

Rawick, George P. 1972. From Sundown to Sunup: The making of the black community. Greenwood Publishing Company.

Reece, Robert L., and Heather A. O'Connell. 2016. "How the legacy of slavery and racial composition shape public school enrollment in the American south." Sociology of Race and Ethnicity 2: 42-57.

Reed, Isaac Ariail. 2013. "Power: Relational, Discursive, and Performative Dimensions." Sociological Theory 31:198-218.

Ruef, Martin. 2004. "The Demise of an Organizational Form: Emancipation and Plantation Agriculture in the American South, 1860-1880." American Journal of Sociology 109: 1365-1410.

---. 2012. "Constructing Labor Markets The Valuation of Black Labor in the US South, 1831 to 1867." American Sociological Review 77:970-98. 
Rule, Alix, Jean-Philippe Cointet, and Peter S. Bearman. 2018. "Lexical shifts, substantive changes, and continuity in State of the Union discourse, 1790-2014." Proceedings of the National Academy of Sciences 112: 10837-10844.

Scott, James C. 1990. Domination and the arts of resistance: Hidden transcripts. Yale university press.

---. 2008. Weapons of the weak: Everyday forms of peasant resistance. Yale university Press.

Scott, John. 1990. A Matter of Record: Documentary Sources in Social Research. Cambridge, UK: Polity.

Sivaramakrishnan, Kalyanakrishnan. 2005. "Some Intellectual Genealogies for the Concept of Everyday Resistance." American Anthropologist 107(3):346-55.

Slater, Dan. 2009. "Revolutions, crackdowns, and quiescence: Communal elites and democratic mobilization in Southeast Asia." American Journal of Sociology 115:203-254.

Stampp, Kenneth Milton. 1964. The Peculiar Institution: Negro Slavery in the American South. London: Eyre \& Spottiswoode.

Swartz, David. 2012. Culture and power: The sociology of Pierre Bourdieu. University of Chicago Press.

Tilly, Charles. 1991. "Domination, Resistance, Compliance ... Discourse.” Sociological Forum 6(3):593602.

---. 1998. Durable Inequality. Univ of California Press.

Taylor, Verta. 1989. “Social Movement Continuity: The Women's Movement in Abeyance.” American Sociological Review 54:761-775.

Toutanova, Kristina, and Christopher D. Manning. 2000. "Enriching the Knowledge Sources Used in a Maximum Entropy Part-of-Speech Tagger." Pp. 63-70 in Proceedings of the 2000 Joint SIGDAT conference on Empirical methods in natural language processing and very large corpora Association for Computational Linguistics.

Weber, Max. 1947. From Max Weber: Essays in Sociology. Translated, Edited and with an Introduction by HH Gerth and C. Wright Mills. Kegan Paul.

Weinstein, Allen, Gatell, Frank Otto, and David Sarasohn. 1968. American Negro Slavery: a modern reader. Oxford University Press.

White, Deborah Gray. 1985. Ar'n't I a Woman? Female Slaves in the Plantation South. Norton. 


\section{Methodological Appendix}

Semantic netework analysis represents a set of approaches that use the relationship between texts based on overlapping words to construct an overall roadmap of a corpus. Social scientists, alongside computer scientists, have made tremendous gains in developing such techniques to formalize the analysis of unstructured text data (Bail 2014; Börner, Chen, and Boyack 2003). This includes work on Twitter automating the analysis of sentiment (Bollen, Mao, and Pepe 2011), to work in political science tracing the evolution of congressional debates (Quinn et al. 2010), to analyses of historical data (Moody, Faris and Bearman 1999; Bearman and Stovel 2000; identifying reference 2016). We have only begun to scratch the surface, however, particularly when it comes to integrating formal network analytic techniques (which can reveal important patterns) with more traditional qualitative engagement (which can offer leverage regarding underlying processes, meaning, context, etc.) (see especially Bail 2014; Mohr and Bogdanov 2013; Pachucki and Breiger 2010; identifying reference 2014). It is with this dual and complementary objective in mind that we construct co-word networks-networks that serve as thematic maps of the slave narrative corpus and that help identify core domains of social life within which the dynamics of resistance, quiescence and agency might be enacted. We then draw on these network maps to guide our qualitative immersion into the narratives themselves - immersion that affords leverage on key content as well as the relative prevalence of symbolic and collective resistance, quiescence and agency across primary interactional domains highlighted in the networks.

This analytic strategy — combining text networks with qualitative immersion — offers a balanced approach to navigating macro and/or formal methods while also remaining sensitive to the depth of texts themselves and generalizing from smaller samples. ${ }^{4}$ This offers several advantages in our case, including

\footnotetext{
${ }^{4}$ Formal modeling of texts may be particularly useful when thinking of datasets that contain tens of thousands of tweets or emails. At the same time, close textual engagement can generate important and distinct socio-historical insights regarding action and inaction. We believe that the combination of techniques is the most promising, however, for comparative historical analyses involving dozens or even hundreds of texts. Scholars should also continue exploring natural language processing techniques, like topic modeling or word embeddings, for analyzing very large text corpora.
} 
but not limited to: (1) A depiction of 128 narratives, comprising millions of words and representing thousands of personal experiences; (2) the ability to validate the interconnections between narratives, thereby bolstering confidence in conclusions drawn from this necessarily convenient sample; (3) the highlighting of dominant relational fields of life under enslavement in the United States, and; (4) systematic sociological immersion into experiences of slavery, resistance and the contexts surrounding them.

\section{Constructing Co-word Networks}

The construction of co-word networks, the first step in our analyses, involves several stages. Consistent with other text analyses (see Diesner and Carley 2005; Hoffman et al. 2018; Leydesdorff and Hellsten 2005; Rule, Cointet, Bearman 2015), we (1) processed each of the texts, removing extraneous information such as symbols, numbers and html codes. Only text pertaining to the actual narrative was included (i.e., bibliographic information was removed). Next, we (2) removed uninformative words, such as participles and prepositions, by comparing the text to a standard stop list. $^{5} \mathrm{We}(3)$ stemmed each of the concepts using the popular porter-stemmer algorithm (Porter 1980), so that words were identified by their common roots. We (4) identify words that appear in proximity to one another or skip-grams proximate within 8 words and (5) constructed normalized probabilities of words appearing in close proximity to one another given that they appear with some frequency $(n>20)$ following Silge and Robinson (2017, see also Silge (2017) and Bail (nd)) and drawing heavily on the tidytext package in R (2016). Next, we (6) reduced the terms to the top 300 most frequent due to visualization limitations - it is hard to make sense of a graph with an abundance of nodes - and consistent with our goal of visualizing prominent corpus-wide themes. We (7) construct a word-to-word cosine distance matrix based on the normalized skip-gram similarities and (8) build a network from this adjacency matrix. In this network, the nodes are words and the edges

\footnotetext{
${ }^{5}$ These words are uninformative from a content perspective, yet as Pennebaker, Mehl, and Niederhoffer (2003) describe, they are informative when attempting determine stylistic differences between texts and authors.
} 
are weighted by the cosine distance scores between the words based on their co-occurrence in texts.

Themes that appear together in the narratives will be closer together within the network.

\section{Appendix References}

Bail, Christopher A. 2014. "The Cultural Environment: Measuring Culture with Big Data." Theory and Society 1-18.

---. N.d. "Word Embeddings.” Retrieved on May 4, 2020

(https://cbail.github.io/textasdata/word2vec/rmarkdown/word2vec.html).

Bearman, Peter S., and Katherine Stovel. 2000. "Becoming a Nazi: A Model for Narrative Networks." Poetics 27:69-90.

Bollen, Johan, Mao, Huina, \& Pepe, Alberto 2011. Modeling public mood and emotion: Twitter sentiment and socio-economic phenomena. In Proceedings of the Fifth International AAAI Conference on Weblogs and Social Media.

Börner, Katy, Chaomei Chen, and Kevin W. Boyack. 2003. "Visualizing Knowledge Domains." Annual Review of Information Science and Technology 37(1):179-255.

Diesner, Jana and Kathleen M. Carley. 2005. "Revealing Social Structure from Texts: Meta-Matrix Text Analysis as a Novel Method for Network Text Analysis." Causal mapping for information systems and technology research: Approaches, advances, and illustrations 81-108.

Hoffman, Mark Anthony, Jean-Philippe Cointet, Philipp Brandt, Newton Key, and Peter Bearman. 2018. "The (Protestant) Bible, the (printed) sermon, and the word (s): The semantic structure of the Conformist and Dissenting Bible, 1660-1780." Poetics 68: 89-103.

Leydesdorff, Loet and Iina Hellsten. 2005. "Metaphors and Diaphors in Science Communication: Mapping the Case of Stem Cell Research." Science Communication 27:64-99.

Mohr, John W., and Petko Bogdanov. 2013. "Introduction-Topic Models: What They Are and Why They Matter.” Poetics 41(6):545-69.

Moody, James, Robert Faris, and Peter S. Bearman. 1999. "Blocking the Future: New Solutions for Old Problems in Historical Social Science.” Social Science History 23:501-533.

Pachucki, Mark A., and Ronald L. Breiger. 2010. "Cultural Holes: Beyond Relationality in Social Networks and Culture." Annual Review of Sociology 36:205-24.

Pennebaker, James W., Matthias R. Mehl, and Kate G. Niederhoffer. 2003. "Psychological Aspects of Natural Language Use: Our Words, Our Selves.” Annual Review of Psychology 54(1):547-77.

Porter, Martin F. 1980. “An Algorithm for Suffix Stripping." Program: electronic library and information systems 14(3):130-37. 
Quinn, K. M., B. L. Monroe, M. Colaresi, M. H. Crespin, and D. R. Radev. 2010. "How to Analyze Political Attention with Minimal Assumptions and Costs." American Journal of Political Science 54(1):209-28.

Rule, Alix, Jean-Philippe Cointet, and Peter S. Bearman. 2018. "Lexical shifts, substantive changes, and continuity in State of the Union discourse, 1790-2014." Proceedings of the National Academy of Sciences 112: 10837-10844.

Silge, Julia. 2017. "Word Vectors with tidy data principles." Retrieved March 4, 2020 (https://www.rbloggers.com/word-vectors-with-tidy-data-principles/).

Silge, Julia, and David Robinson. 2017. Text mining with R: A tidy approach. O'Reilly Media, Inc.

---. 2016. "tidytext: Text mining and analysis using tidy data principles in R." Journal of Open Source Software 1: 37. 
Table 1. Overview of Thematic Clusters

\begin{tabular}{llllll}
\hline & & Average & \multicolumn{3}{c}{ Most Popular Words } \\
Community & Size & Betweenness & 1 & 2 & 3 \\
\hline Everyday Life & 41 & 567 & time & day & night \\
Slave \& Master & 34 & 667 & slave & master & hand \\
Faith \& Prayer & 32 & 414 & god & lord & heart \\
Church \& Institutions & 23 & 770 & church & meet & school \\
Family & 19 & 461 & mother & friend & children \\
Slavery \& Race & 15 & 234 & peopl & white & color \\
Place \& War & 15 & 566 & hous & door & water \\
Narration \& Literacy & 14 & 350 & told & life & follow \\
Economics & 14 & 515 & dollar & money & hundr \\
Politics & 10 & 544 & free & countri & citi \\
Life Course & 10 & 409 & live & littl & boy
\end{tabular}


Figure 1. Theoretical Matrix of Resistance

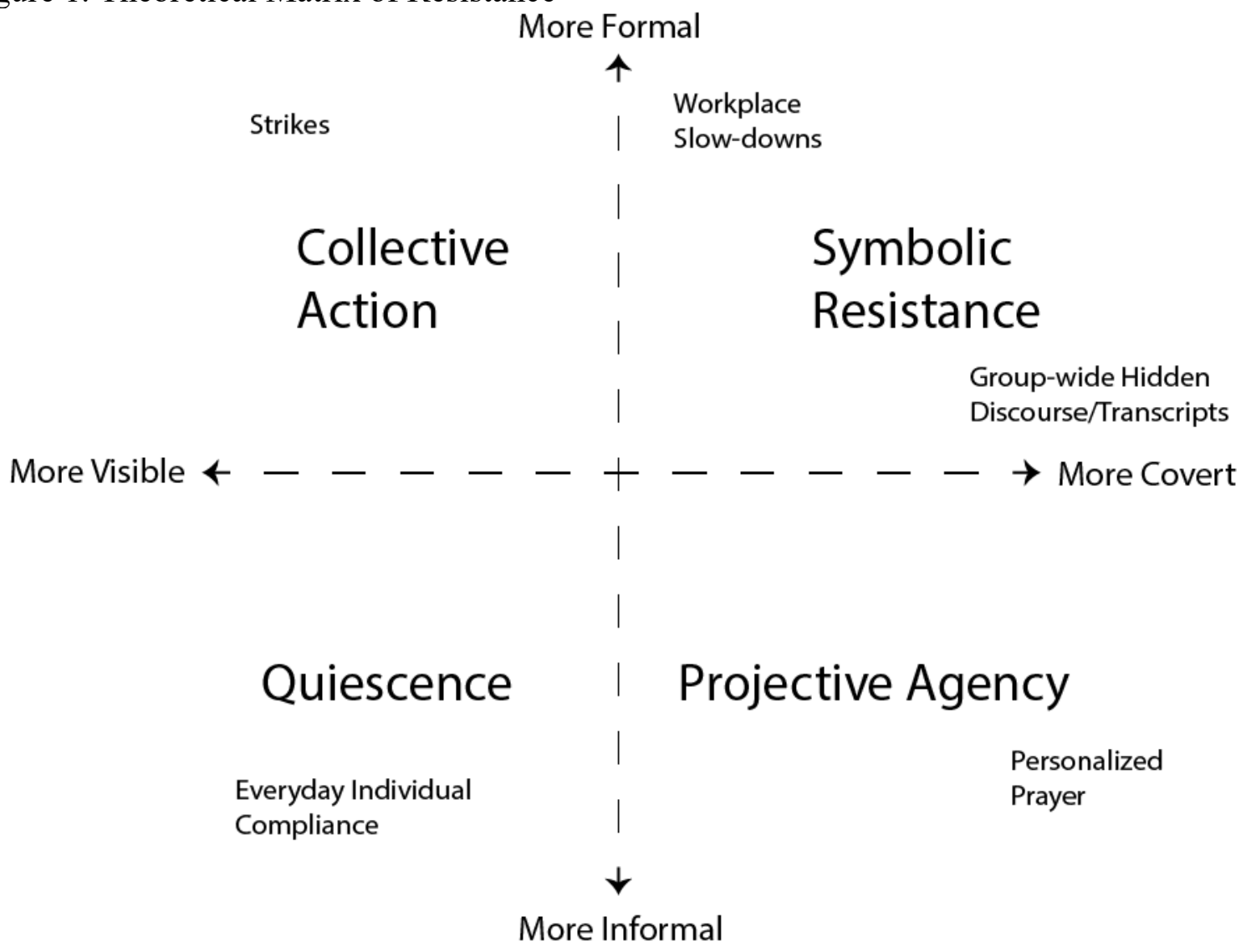


Figure 2. Geographic Distribution of Narrative Sample

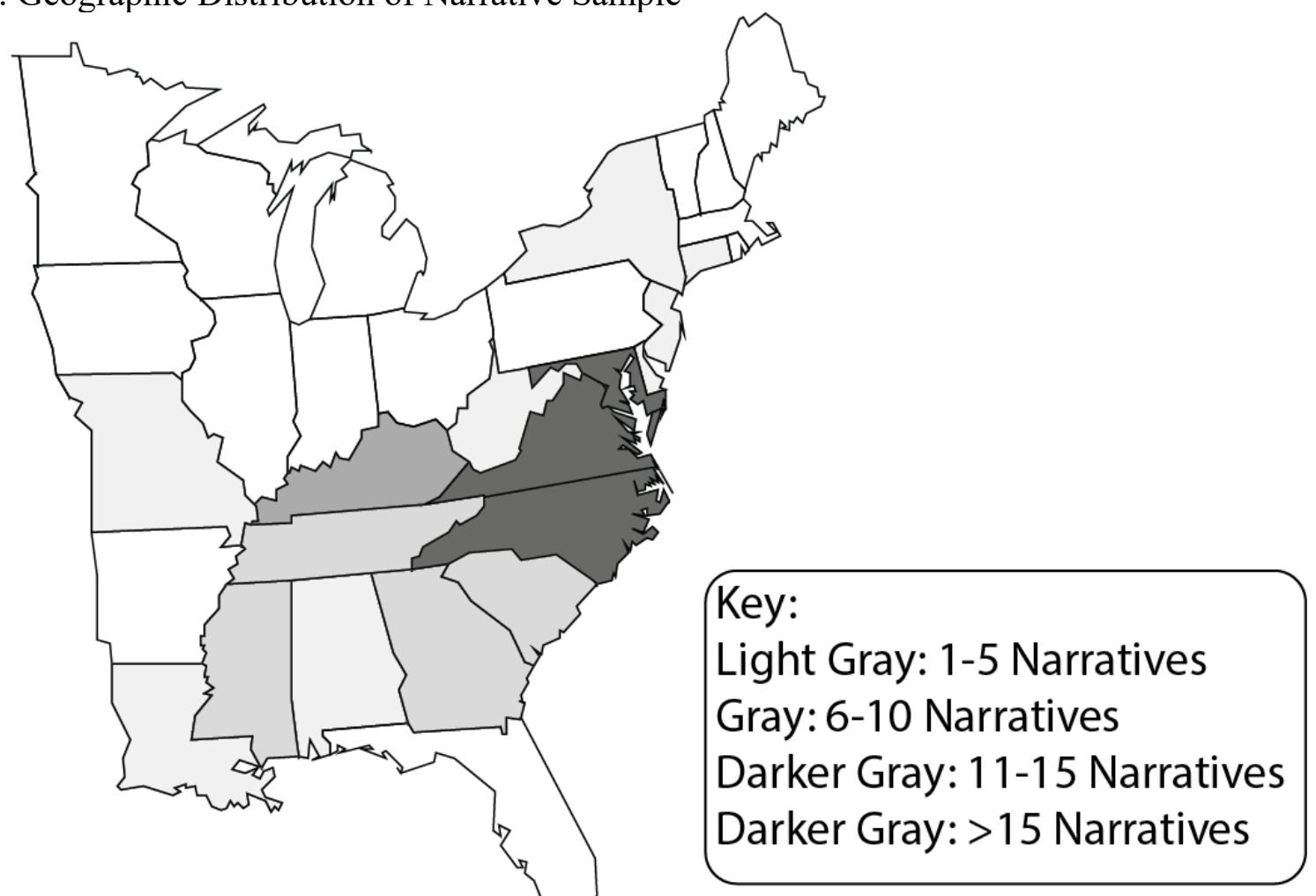


Figure 3. Slave Narrative Corpus Text Network

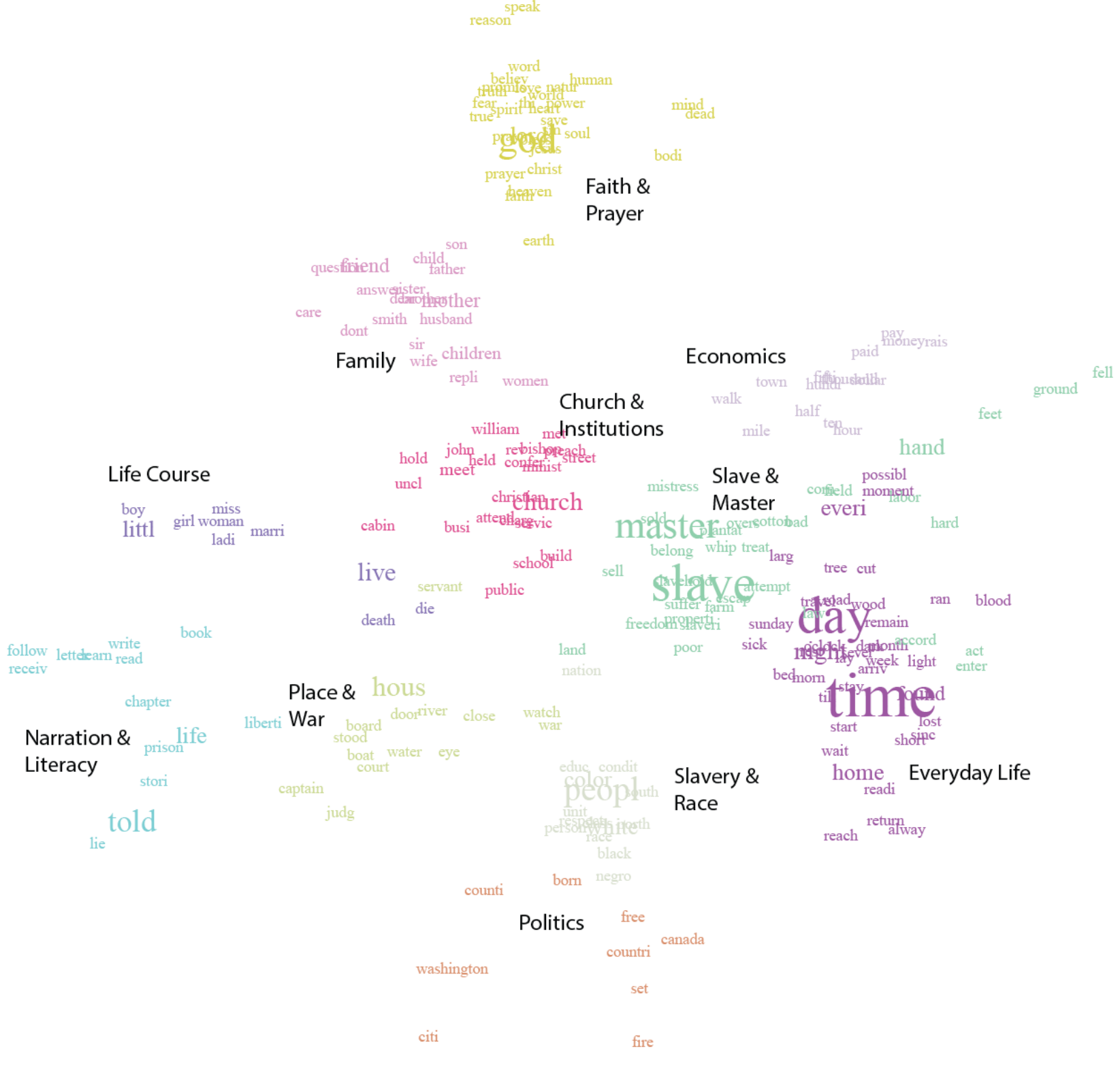

york

Note: Communities indicated by color identified by Louvain community detection. Word size varies by frequency within corpus. Edge strength determined by cosine distance scores, but edges suppressed in visualization for legibility. 
Figure 4. Slave Narrative Thematic Clusters Network

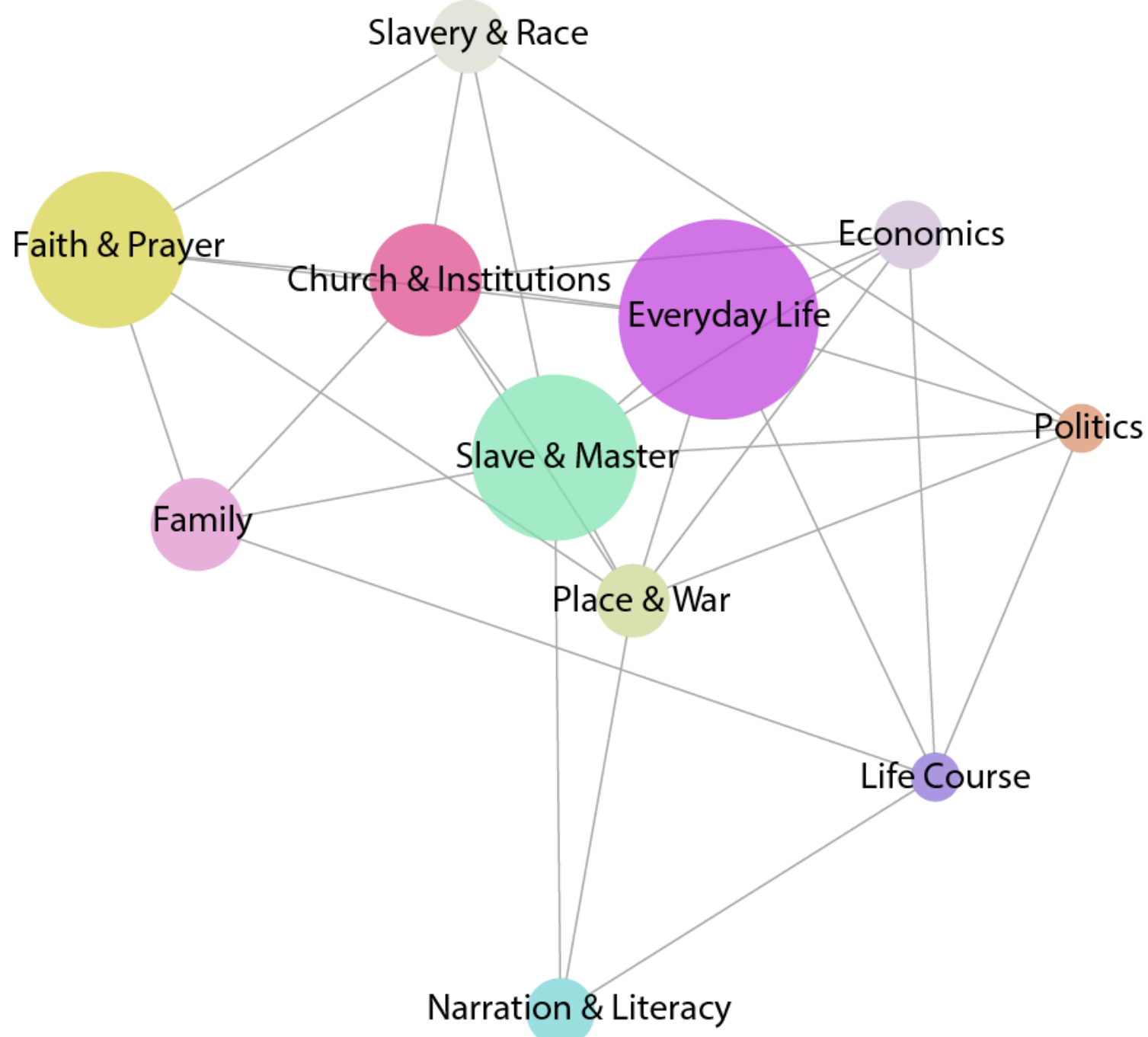

Note: Node size indicates size of community. Node color corresponds with communities in figure 3. Unweighted edges based on connections between words across communities. 
Figure 5. Center of Slave Narrative Text Netwrok

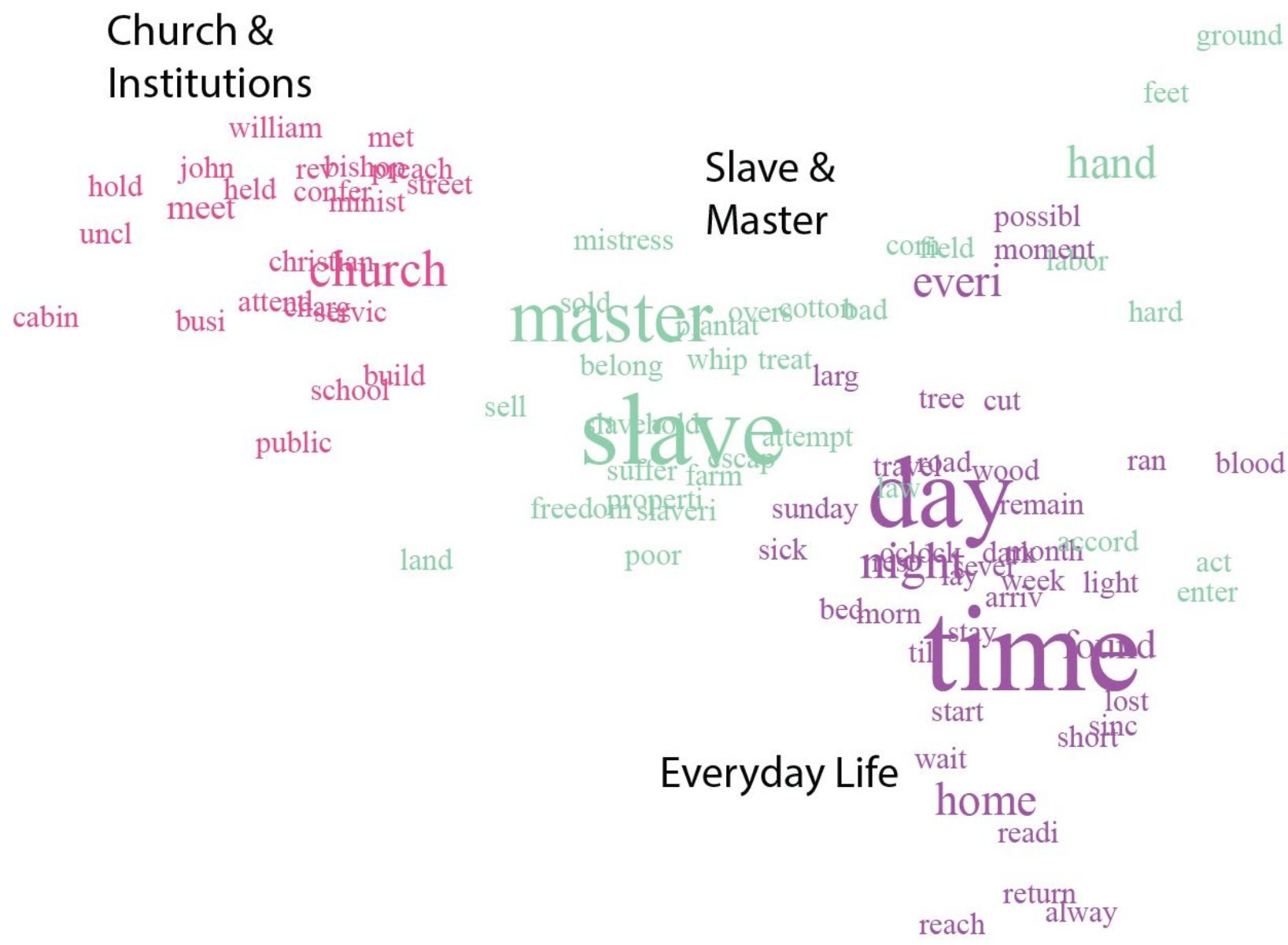

Note: Communities indicated by color identified by Louvain community detection. Word size varies by frequency within corpus. Edge strength determined by cosine distance scores, but edges suppressed in visualization for legibility. 